\title{
Fecal incontinence due to retrorectal hematoma: Report of a case
}

\author{
Retrorektal hematoma bağlı gaita inkontinansı: Olgu sunumu
}

Hatim Yahya USLU1 ${ }^{1}$, Ahmet Hakan HALILOĞLU²

Departments of, ${ }^{1}$ General Surgery, ${ }^{2}$ Urology, Ufuk University School of Medicine, Ankara

We report herein a young patient with fecal and urinary incontinence due to a retrorectal hematoma. A 15-year-old male admitted with the complaints of being unable to walk or lie down on his back and no urinary bladder or anal sphincter control. His history revealed a pelvic trauma a few weeks before his admission. His complaints were mild at first and progressed over time. Preoperative studies revealed retrorectal hematoma and neurogenic bladder. Laparotomy was performed, and the hematoma was evacuated. In the early postoperative period, the patient's complaints decreased; he was able to lie down on his back and abduct/adduct his lower extremities, and he showed complete control of passage of the rectum contents. However, urinary bladder control was not yet achieved at it requires a longer period of time.

Key words: Pelvic hematoma, anal incontinence, retrorectal mass

\section{INTRODUCTION}

Retroperitoneal pelvic masses are lesions that occur due to different etiologies. Congenital cysts, tumors and hematomas are the most common presenting lesions. Pelvic hematomas can occur after angiographic intervention, percutaneous prostate biopsy, ilioinguinal nerve block, pelvic trauma, or due to bleeding into a congenital retroperitoneal cyst (1-4). Retroperitoneal pelvic masses can be diagnosed as retrorectal masses when formed behind the rectum. Retrorectal masses are common lesions that can be classified as congenital, inflammatory, neurogenic, osseous, or miscellaneous (4-7). The clinical presentations of patients affected by these masses depend on their size and location within the pelvis. Small masses can be asymptomatic and discovered by chance during digital examination or on radiological studies for an unrelated pathology. Lower extremity and back pain, abdominal distention, hematuria, and anuria are some of the reported presenting symptoms $(8,9)$. Biopsy of these lesions should be avoided until the diagnosis is clear; otherwise, tumor seeding, fecal fistula, meningitis, or abscess formation may follow.

Complete surgical resection or drainage, usually after appropriate specialized imaging studies, remains the cornerstone of the treatment (6).

A 15-year-old patient was admitted to our hospital with back pain and inability to walk properly, lie down on his back, or to control the passage of feces and urine.
Bu olgu sunumumuzda, fekal ve üriner inkontinansı olan, retrorektal hematomlu genç hastamızı sunuyoruz. Mesane ve anal sfinkter kontrolü kaybolan 15 yaşındaki erkek hastanın yürüyüşü de günlük hayatını idame ettiremeyecek kadar bozulmuştu. Hastanın anamnezinde aylar önce spor yaparken geçirdiği pelvik travma öyküsüne rastlandi. Hasta travmadan bir süre sonra artan şikayetlerinden yakınmaya başlamış. Preoperative yapılan tetkiklerde hastada retrorektal hematom ve nörojenik mesane tespit edildi. Laparotomi yapılarak hastanın hematomu boşaltıldı. Postoperative saatler içinde alt ekstremitelerde abduktor ve adduktor kaslarda belirgin düzelme gözlendi. Günler içinde anal sfinkter kontrolü tama yakın olarak normale döndü. Ancak nörojenik mesanenin düzelmesi zaman alacağı için temiz aralıklı kataterizasyon uygulamasına başlandi.

Anahtar kelimeler: Pelvis hematom, anal inkontinas, retrorektal kitle

His history revealed a pelvic trauma a few weeks before his admission. He fell down on his hip while playing volleyball. Because of the progression of his complaints, he visited more than one medical center seeking help, eventually presenting to our center. Upon his admission, his painful facial expression and inability to stand in an upright position were noted. He was unable to control his urinary and fecal passage. There was no control of the passage of any rectal contents (gas, fluid or solid). The preoperative Jorge and Wexner scoring system evaluation revealed complete incontinence, whereas the postoperative evaluation revealed continence (Table 1).

His physical examination revealed normal vital signs and back pain during deep abdominal palpations. On anal digital examination, a giant mass with rubbery consistency was palpated immediately upon finger insertion into the anal canal. The sphincter tonus was found to be weak. Six pads were needed daily to keep the patient dry. The neurological examination revealed no sensory or motor deficit. The deep tendon reflexes were found to be normal. His blood biochemistry revealed no abnormality. His complete blood count revealed leukocytosis with neutrophil predominance. Voiding cystourethrography revealed irregular bladder surface. Cystometric study revealed neurogenic urinary bladder. Transperineal ultrasonography, pelvic computerized tomography and magnetic resonance revealed a giant retrorectal hematoma that 


\begin{tabular}{|c|c|c|c|c|c|c|c|}
\hline $\begin{array}{l}\text { Type of } \\
\text { incontinence }\end{array}$ & Never & <once/month & >once/month & $\begin{array}{l}\text { Frequency } \\
\quad>\text { once/week }\end{array}$ & ?once/day & Preop & Postop \\
\hline Solid & 0 & 1 & 2 & 3 & 4 & 4 & 0 \\
\hline Liquid & 0 & 1 & 2 & 3 & 4 & 4 & 0 \\
\hline Gas & 0 & 1 & 2 & 3 & 4 & 4 & 0 \\
\hline Requires pad & 0 & 1 & 2 & 3 & 4 & 4 & 0 \\
\hline \multirow[t]{2}{*}{ Lifestyle alteration } & 0 & 1 & 2 & 3 & 4 & 4 & 0 \\
\hline & & & & & & 20 & 0 \\
\hline \multicolumn{8}{|l|}{$0=$ normal continence } \\
\hline $20=$ total incontinence & & & & & & & \\
\hline
\end{tabular}

displaced the rectum anteriorly and to the left (Figure 1). Preoperative anal manometer revealed decreased resting and squeezing pressures.

Laparotomy was performed. On exploration, a giant retrorectal soft mass displacing the rectum anteriorly and to the left was observed. The rectum was mobilized and the mass was dissected. During dissection, the mass capsule ruptured and some organized blood leaked. The anterior wall of the hematoma capsule was then resected and the remainder of the cavity content was evacuated completely. The cavity was irrigated with $0.9 \% \mathrm{NaCl}$, a drain was placed into the empty cavity, and the abdominal wall was closed in anatomic order. The resected capsule wall was sent to the pathology department, and the pathology result revealed hematoma capsule wall.

In the first few postoperative days, we observed a dramatic decrease in the patient's symptoms. Back and lower extremity pain decreased. The patient was able to lie down on his back, stand up, abduct the lower extremity, and control his anal function; pads were no longer needed to keep him dry.

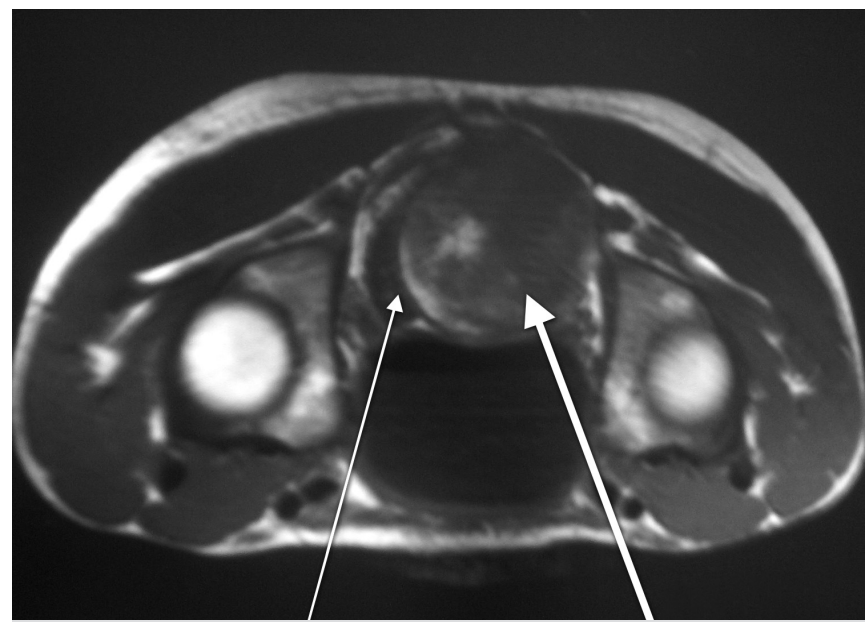

Figure 1. Pelvic CT scan: The thick arrow indicates the pelvic hematoma, while the thin arrow shows the displaced rectum.

\section{DISCUSSION}

Fecal incontinence is a distressing condition, and may lead to social discomfort, with a final result of an individual's isolation from society. The incidence is unknown; however, it is more common in women than men, with a female:male ratio of 8:1 (10). To our knowledge, this is the first case of pelvic hematoma located retrorectally and leading to urinary and fecal incontinence. There have been many published reports of pelvic hematoma, but none of them reported fecal incontinence as a presenting symptom or as a final result of pelvic hematoma. Dysuria and urinary frequency due to neural or bladder compression have been reported $(11,12)$. Pelvic hematomas resulting in anuria due to bilateral ureter obstruction and massive hematuria due to urinary bladder perforation have been reported as well $(8,9)$. The location of a hematoma within the pelvis and its size play an important role in the patient's presenting symptoms. Our patient experienced none of the symptoms at first; however, the mass grew in size, leading to the final symptoms and physical findings as previously mentioned.

The reason for the fecal incontinence in this case was a combination of mechanical and neural factors. The rectum capacity was decreased since it was pushed to the anterior and compressed against the lateral pelvic wall (Figure 1); the disruption of the flutter and flap valve (theoretically considered to play a role in fecal continence) mechanism was the mechanical factor considered. On the other hand, compression of the neural plexus innervating the rectum, anal canal and the urinary bladder led to disruption in their function. This was supported by abnormal anal resting and squeezing pressures on the anal manometer study and the high preoperative Jorge Wexner score. We could not perform other studies such as electromyography, which may have lent further support to the results. Evacuation of the hematoma led to pressure relief for both the neural plexus and the rectum, which subsequently led to resumption of normal anal continence. The postoperative Jorge Wexner score of 0 supported the fact that the 
incontinence was caused by the hematoma formation. Postoperative anal manometer could not be performed.

The surgical procedure utilized in this patient's treatment may be the subject of debate. Surgical treatment of retrorectal masses can be achieved by posterior sagittal trans-sacral, anterior transperitoneal or transanal endoscopic approach (13).We treated our patient with anterior transperitoneal approach. The patient may have been treated with a less invasive method, like laparoscopic or transanal endoscopic method. However, due to our lack of experience with such a case, we considered that the patient's symptoms may be due to more than a hematoma alone, perhaps a retrorectal tumor

\section{REFERENCES}

1. Anjum MI. Pelvic hematoma following trucut biopsy of the prostate. Int Urol Nephrol 1996; 28: 781-5.

2. Viasman J. Pelvic hematoma after an ilioinguinal nerve block for orchialgia. Anesth Analg 2001; 92: 1048-9.

3. Zhang FQ, Zhang YZ, Pan JS, et al. Pelvic compartment syndrome caused by retroperitoneal hematoma of pelvic fracture. Chin Med J (Engl) 2005; 118: 877-8.

4. Ottery FD, Carlson RA, Gould H, Weese JL. Retrorectal cyst-hamartomas: CT diagnosis. J Comput Assist Tomogr 1986;10: 260-3.

5. Negro F, Mercuri M, Ricciardi V, et al. Presacral epidermoid cyst. A case reportAnn Ital Chir 2006; 77: 75-7.

6. Hobson KG, Ghaemmaghami V, Roe JP, et al. Tumors of the retrorectal space.Dis Colon Rectum 2005;48: 1964-74.

7. Erden A, Ustuner E, Erden I, et al. Retrorectal dermoid cyst in a male adult: case report. Abdom Imaging 2003; 28: 725-7. complicated with hemorrhage that led to the hematoma formation. We thus preferred an open surgery to explore and treat simultaneously. Otherwise, this case could very easily have been treated by laparoscopic or transanal approach. Laparoscopic hematoma evacuation could have been possible providing all the advantages of laparoscopic surgery. Posterior sagittal trans-sacral approach could be considered in invasive retrorectal tumors. Fecal incontinence is a disturbing benign disorder that can develop due to different etiologies. In this case report, retrorectal hematoma as a cause of anal incontinence is described for the first time.

8. Flint P, Allen CF. Pelvic fracture complicated by bilateral ureteral obstruction: case report. J Trauma 1994; 36: 285-7.

9. Lane BR, Moy ML, Frenkl T, et al. Pelvic hematoma as a cause of bladder perforation and gross hematuria. Urology 2004; 64: 1030.

10. Johnson JF, Lattery J. Epidemiology of fecal incontinence: the silent affliction. Am J Gastroenterol 1996; 91: 33-6.

11. Brooks BS, Duvall ER, El Gammal T, et al. Neuroimaging features of neurenteric cysts: analysis of nine cases and review of the literature. AJNR Am J Neuroradiol 1993; 14: 735-46.

12. Williams LS, Rojiani AM, Quisling RG, Mickle JP. Retrorectal cyst-hamartomas and sacral dysplasia: MR appearance. AJNR Am J Neuroradiol 1998;19: 1043-5.

13. Zoller S, Joos A, Dinter D, et al. Retrorectal tumors: excision by transanal endoscopic microsurgery. Rev Esp Enferm Dig 2007; 99: 547-50. 